\title{
ANALISIS PERTUMBUHAN EKONOMI DAN PERGESERAN ANTAR SEKTOR EKONOMI DI KABUPATEN BANGGAI LAUT PROVINSI SULAWESI TENGAH
}

\section{Analysis Of Ekocomic Growth And Shifting Between Economic Sektor In Banggai Laut Districk Of Central Sulawesi Province}

\author{
Anastasia D'ornay S. E, M. Pd ${ }^{1}$ \\ Email:anastasia.dornay@gmail.com \\ STIE AMSIR PAREPARE \\ Maskur Hasan S. E, M. Si \\ Email; maskur.hasan@gmail.com \\ STIE AMSIR PAREPARE \\ Ulfa Natsir S. Sy, M. Si ${ }^{3}$ \\ Email; pulfanatsir@gmail.com \\ STIE AMSIR PAREPARE
}

\begin{abstract}
ABSTRAK
Penelitian ini bertujuan untuk : (1) mengidentifikasi klasifikasi pertumbuhan sektor perekonomian di Kabupaten Banggai Laut, (2) mengetahui pengaruh pergeseran antar sektor terhadap pertumbuhan PDRB Kabupaten Banggai Laut, dan (3) mengetahui sektor-sektor basis ekonomi di Kabupaten Banggai Laut. Penelitian ini menggunakan data sekunder. Teknik pengumpulan data menggunakan dokumentasi dan wawancara. Analisis data yang digunakan adalah SSA (Shift Share Analisis) dan LQ (Location Quotient). Hasil penelitian berdasarkan analisis Shift Share menunjukkan bahwa telah terjadi perubahan struktur ekonomi di Kabupaten Banggai Laut dari sektor primer ke sektor sekunder dan tersier. Hal ini ditunjukkan dengan peranan sektor sekunder dan tersier yang terus meningkat melalui besarnya kontribusi terhadap PDRB Kabupaten Banggai Laut namun secara keseluruhan pertumbuhan ekonomi Kabupaten Banggai Laut tergolong lamban. analisis Location Quotient menunjukkan yang merupakan sektor unggulan atau merupakan sektor basis yaitu sektor pertanian, listrik dan air bersih, perdagangan hotel dan restoran, dan sektor keuangan dan persewaan.
\end{abstract}

Kata Kunci : Sektor Basis Ekonomi, Shift Share Analysis.

\section{ABSTRACT}

This study aims to: (1) identify the classification of growth sectors of the economy in Banggai Laut, (2) the effect of shift between sectors to GDP growth Banggai Laut, and (3) determine sectors of the economic base in Banggai Laut. This study uses secondary data. Data collection techniques using documentation and interviews. Analysis of the data used is SSA (Shift Share Analysis) and LQ (Location Quotient). The results based on the Shift Share analysis indicates that there has been a change in the economic structure in Banggai Laut from the primary sector to the secondary and tertiary sectors. This is shown by the role of secondary and tertiary sectors continues to increase by the amount of contribution to GDP Banggai Laut but overall economic growth relatively slow Banggai Laut. Location Quotient 
analysis indicates that the dominant sector or a sector basis, namely agriculture, electricity and water supply, trade, hotels and restaurants, and finance and leasing sector.

Keyword: Economic Sector, Shift Share Analysis.

\section{PENDAHULUAN}

Pada dasarnya pembangunan regional tidak bisa dilepaskan kaitannya dengan pembangunan nasional, salah satu sasaran pembangunan nasional Indonesia adalah menciptakan pertumbuhan ekonomi dan pemerataan hasil pembangunan, termasuk di dalamnya pemerataan pendapatan antar daerah (wilayah). Untuk mencapai sasaran di atas bukanlah pekerjaan ringan karena pada umumnya pembangunan ekonomi suatu daerah berkaitan erat dengan potensi ekonomi dan karakteristik yang dimilikinya.

Pembangunan ekonomi daerah mempunyai tujuan utama yaitu meningkatkan jumlah dan jenis peluang kerja untuk masyarakat local, dalam upaya untuk mencapai tujuan tersebut, pemerintah daerah dan masyarakatnya harus secara bersama-sama mengambil inisiatif membangun daerahnya. Oleh karena itu pemerintah daerah harus berupaya menggunakan sumber daya yang ada di daerah tersebut dengan sebagaimana mestinya untuk kemakmuran rakyat banyak dan mendorong perekonomian untuk maju.

Bila memperbandingkan pertumbuhan antara daerah, maka akan ditemui kenyataan bahwa ada daerah yang tumbuh lebih cepat diantaranya disebabkan oleh struktur ekonominya sebagian besar mempunyai laju pertumbuhan yang cepat. Sebaliknya bagi daerah yang pertumbuhannya lambat, sebagian besar sektor ekonominya mempunyai laju pertumbuhan yang lambat.

Salah satu tujuan pembangunan adalah meningkatkan pertumbuhan ekonomi, dengan pertumbuhan ekonomi yang tinggi tentu akan dapat dirasakan manfaatnya oleh masyarakat luas. Indikator penting untuk mengetahui kondisi ekonomi suatu wilayah atau daerah dalam suatu periode tertentu ditunjukkan oleh data Produk Domestik Regional Bruto (PDRB) wilayah atau daerah tersebut. Pertumbuhan ekonomi adalah salah satu indikator penting dalam melakukan analisis tentang pembangunan ekonomi yang terjadi pada suatu negara. Pertumbuhan ekonomi menunjukkan sejauh mana aktivitas perekonomian akan menghasilkan tambahan pendapatan masyarakat pada suatu periode tertentu. Di samping analisis pertumbuhan ekonomi dapat digunakan untuk menentukan keberhasilan pembangunan yang telah dicapai dapat pula digunakan untuk menentukan arah pembangunan yang akan datang.

Perhatian terhadap pertumbuhan ekonomi wilayah semakin meningkat dalam era otonomi daerah. Hal ini cukup logis, karena dalam era otonomi tersebut masing-masing 
daerah berlomba-lomba meningkatkan pertumbuhan ekonomi daerahnya guna mendorong perbaikan kemakmuran masyarakat setempat. Karena itu, pembahasan mengenai struktur dan faktor penentu pertumbuhan ekonomi daerah akan sangat penting artinya bagi Pemerintah Daerah dalam menentukan kebijakan dan upaya yang dapat dilakukan untuk mendorong pertumbuhan ekonomi di daerahnya masing-masing (Sjafrizal 2014)

Adisasmita (2013) menjelaskan bahwa berbagai wilayah (regions) memiliki karakteristik yang bervariasi, berbeda-beda secara fisik (aspek geografi, topografis, klimatologis, geologis, dan lainnya), secara ekonomis (aspek pendapatan per kapita, potensi kekayaan sumber daya alam, perkembangan sektor pertanian, industri dan lainnya), secara sosial (aspek kependudukan, aspek pendidikan, dan aspek kesehatan), serta dari aspek keprasaranaan dan sarana pembangunan.

Karena perbedaan potensi, kondisi dan permasalahan yang dihadapi, maka diperlukan penanganan pembangunan yang berbeda dan harus disesuaikan dengan wilayah yang bersangkutan.

Kesungguhan pemerintah dalam membangun daerah ini diukur dengan adanya suatu sistem pemerintahan yang dikenal dengan istilah Otonomi daerah. Untuk mendukung hal itu pemerintah mengeluarkan Undang-undang Nomor 22 Tahun 1999 tentang Pemerintahan Daerah yang kemudian direvisi menjadi Undang-undang No.32 Tahun 2004 dan Undangundang Nomor 25 Tahun 1999 tentang Perimbangan Keuangan antara Pemerintah Pusat dan Daerah yang kemudian direvisi menjadi Undang-undang Nomor 33 Tahun 2004.

Undang-undang tersebut merupakan landasan bagi daerah untuk membangun daerahnya secara mandiri dengan lebih mengandalkan kemampuan dan potensi yang dimiliki daerah. Undang-undang ini juga memberikan kewenangan yang lebih besar (local discretion) kepada daerah untuk merancang berbagai program pembangunan yang sesuai dengan keinginan masyarakat setempat (local needs).

Salah satu indikator kemajuan perekonomian suatu daerah dapat dilihat dari pertumbuhan ekonomi secara agregat dapat dihitung melalui Produk Domestik Bruto (PDRB) yang rata-rata tertimbang dari tingkat pertumbuhan sektoralnya, artinya apabila suatu sektor mempunyai kontribusi besar dan pertumbuhannya sangat lambat maka hal ini dapat menghambat tingkat pertumbuhan ekonomi secara agregatif. Sebaliknya apabila suatu sektor mempunyai kontribusi yang relatif besar terhadap totalitas perekonomian maka sektor tersebut mempunyai tingkat pertumbuhan yang tinggi dan sekaligus akan dapat lebih meningkatkan pertumbuhan ekonomi. Analisis kontribusi digunakan untuk mengetahui 
besarnya angka PDRB sebagai salah satu indikator yang menunjukkan kemampuan sumber daya yang dihasilkan oleh suatu daerah.

Keberhasilan pelaksanaan pembangunan daerah berkaitan erat dengan kualitas perencanaan pembangunan daerah. Rencana pembangunan daerah tersebut dilaksanakan berdasarkan identifikasi terhadap wilayah perencanaan dan karakteristik wilayah. Karakteristik wilayah perencanaan meliputi berbagai permasalahan dan potensi yang dimiliki daerah. Perencanaan pembangunan suatu daerah diarahkan untuk mengelola sumber daya daerah sehingga dapat menunjang pembangunan ekonomi daerah tersebut.

Tingkat pertumbuhan ekonomi Kabupaten Banggai Laut didukung adanya sektor ekonomi unggulan yang dapat dijadikan potensi daerah bagi perkembangan daerah tersebut. Menurut Tarigan (2014) hal ini sangat penting karena sektor tersebut dapat memberikan dua sumbangan sebagai berikut: 1) Secara langsung meningkatkan perekonomian wilayah melebihi pertumbuhan alamiah, dan 2) Mendorong sektor non basis untuk berkembang.

Kemampuan suatu wilayah untuk tumbuh secara cepat sangat ditentukan oleh berbagai faktor ekonomi yang satu sama lainnya juga saling berkaitan. Faktor-faktor penentu pertumbuhan ekonomi wilayah tersebut perlu diketahui secara rinci berikut sifat-sifatnya. Disamping itu, perlu pula diteliti seberapa besar pengaruh dan kontribusi dari masing-masing faktor tersebut dalam mendorong pertumbuhan ekonomi wilayah tertentu secara keseluruhan. Dari permasalahan diatas, untuk itu dibutuhkan Analisis faktor-faktor ekonomi yang sesuai dengan kemampuan sumber daya (sektor Basis) yang dimiliki setiap daerah di Kabupaten Banggai Laut guna menunjang percepatan pertumbuhan ekonomi di daerah, dan menganalisis pergeseran antar sektor ekonomi guna mengetahui posisi relatif wilayah Kabupaten Banggai Laut terhadap pola perekonomian pada wilayah provinsi.

Dari permasalahan diatas, untuk itu dibutuhkan Analisis faktor-faktor ekonomi yang sesuai dengan kemampuan sumber daya (sektor Basis) yang dimiliki oleh Kabupaten Banggai Laut untuk menunjang percepatan pertumbuhan ekonomi di daerah, dan menganalisis pergeseran antar sektor ekonomi di Kabupaten Banggai Laut agar dapat menjadi acuan pemerintah kabupaten dalam melakukan perencanaan pembangunan ekonomi yang lebih efektif. Penelitan ini betujuan untuk mengetahui bagaimana pergeseran struktur ekonomi, klasifikasi pertumbuhan sektor perekonomian, dan sektor-sektor apa saja yang menjadi sektor basis di Kabupaten Banggai Laut. 


\section{Pergeseran Struktur Ekonomi dan Ukuran Pertumbuhan Ekonomi Daerah}

Analisis Shift Share merupakan salah satu model pertumbuhan ekonomi wilayah yang juga bertujuan untuk mengetahui faktor penentu pertumbuhan ekonomi pada wilayah tersebut (Sjafrizal, 2014). Sementara teori pola pembangunan Chenery memfokuskan terhadap perubahan struktur dalam tahapan proses perubahan ekonomi, industri dan struktur institusi dari perekonomian negara sedang berkembang yang mengalami transformasi dari pertanian tradisional beralih ke sektor industri sebagai roda penggerak ekonomi.

Penelitian yang dilakukan Chenery tentang transformasi struktur produksi menunjukkan bahwa sejalan dengan peningkatan pendapatan perkapita, perekonomian suatu negara akan bergeser dari yang semula mengandalkan sektor pertanian menuju ke sektor industri.

Perubahan struktur ekonomi atau disebut juga transformasi struktural, didefinisikan sebagai suatu rangkaian perubahan yang saling berkaitan satu sama lainnya dalam komposisi dari permintaan agregat, perdagangan luar negeri (ekspor dan impor), penawaran agregat (produksi dan penggunaan faktor-faktor produksi, seperti penggunaan tenaga kerja dan modal) yang disebabkan adanya proses pembangunan dan pertumbuhan ekonomi yang berkelanjutan (Todaro, 2004).

Perekonomian suatu daerah dalam jangka panjang akan terjadi perubahan struktur perekonomian dimana semula mengandalkan sektor pertanian menuju sektor industri. Dari sisi tenaga kerja akan menyebabkan terjadinya perpindahan tenaga kerja dari sektor pertanian desa ke sektor industri kota, sehingga menyebabkan kontribusi pertanian menurun. Faktor penyebab terjadinya perubahan struktur perekonomian antara lain ketersediaan sumber daya alam, sumber daya manusia, sarana dan prasarana serta modal dan investasi yang masuk ke suatu daerah.

Ukuran-ukuran mengenai keterkaitan ekonomi pada dasarnya menggambarkan hubungan antara perekonomian daerah dengan lingkungan sekitarnya. Analisis shift share merupakan teknik yang sangat berguna dalam menganalisis perubahan struktur ekonomi daerah dibanding perekonomian nasional. Analisis ini memberikan data tentang kinerja perekonomian dalam tiga bidang yang berhubungan satu sama lain yaitu: 1) Pertumbuhan ekonomi daerah diukur dengan cara menganalisis perubahan pengerjaan agregat secara sektoral dibandingkan dengan perubahan sektor yang sama diperekonomian yang dijadikan acuan, 2) Pergeseran proporsional mengukur perubahan relatif, pertumbuhan atau penurunan, pada daerah dibandingkan dengan perekonomian yang lebih besar dijadikan acuan. 
Pengukuran ini memungkinkan kita untuk mengetahui apakah perekonomian daerah terkonsentrasi pada industri-industri lebih cepat ketimbang perekonomian yang dijadikan acuan, 3) Pergeseran diferensial membantu kita dalam menentukan seberapa jauh daya saing industri daerah (lokal) dengan perekonomian yang dijadikan acuan. Oleh karena itu, jika pergeseran diferensial dari suatu industri adalah positif, maka industri tersebut lebih tinggi daya saingnya ketimbang industri yang sama pada perekonomian yang dijadikan acuan. (Arsyad, 2004).

\section{Sektor Basis}

Sektor basis memainkan peranan penting sehingga peningkatan besarannya akan membawa pengaruh terhadap peningkatan sektor lainnya. serangkaian teori yang menjelaskan hubungan antara sektor-sektor dalam suatu perekonomian regional satu diantaranya teori basis ekonomi.

Menurut Douglas C. North (dalam Sjafrizal, 2014) pertumbuhan ekonomi suatu wilayah pada dasarnya ditentukan oleh besarnya keunggulan kompetitif yang dimiliki oleh wilayah bersangkutan. Bila suatu wilayah tertentu dapat mendorong pertumbuhan sektorsektor yang mempunyai keuntungan kompetitif sebagai basis untuk kegiatan ekspor, maka pertumbuhan ekonomi wilayah yang bersangkutan akan meningkat cepat. Hal ini dapat terjadi karena peningkatan ekspor tersebut akan memberikan dampak berganda (multiplier effect) yang cukup besar bagi perekonomian daerah yang bersangkutan.

Dalam teori basis ekonomi ini, lebih memusatkan pada kegiatan-kegiatan basis atau ekspor, tetapi tidak melihat pentingnya impor. Suatu peningkatan dalam kesempatan kerja dan pendapatan basis mungkin hanya mempunyai suatu efek pengganda yang sangat terbatas terhadap kegiatan bukan basis jika sebagian besar dari pendapatan ekstra mengalir keluar wilyah dalam bentuk pengeluaran untuk impor. Yang sangat penting dalam hal ini, bahwa suatu perekonomian dapat bertambah tidak hanya dengan peningkatan ekspor dari industri basis tetapi juga dengan mengganti barang-barang impor dari industri basis dengan barangbarang hasil produksi wilayah yang bersangkutan.

Walaupun industri basis merupakan suatu faktor penting yang mendorong perubahan dalam perekonomian regional, namun tidak perlu diragukan bahwa dalam keadaan tertentu kegiatan-kegiatan bukan basis yang sudah berkembang dengan baik dapat menarik masuknya industri basis kedalam suatu daerah dan dengan demikian dapat menjadi salah satu penentu bagi tingkat ekonomi daerah tersebut. 
Selanjutnya dikemukakan bahwa bertambahnya kegiatan basis dalam suatu wilayah akan bertambah arus pendapatan kedalam wilayah yang bersangkutan, menambah permintaan barang dan jasa didalamnya dan menimbulkan kegiatan volume bukan basis. Sebaliknya berkurangnya kegiatan mengekspor barang-barang dan jasa-jasa menyebabkan berkurangnya pendapatan yang masuk ke dalam wilayah yang bersangkutan.

Berbagai penelitian terdahulu yang menyangkut pertumbuhan ekonomi serta pergeseran antar sektor ekonomi :(1). Sutarno (2002), melakukan penelitian tentang pertumbuhan ekonomi dan ketimpangan PDRB per kapita antar kecamatan di kabupaten banyumas tahun 1993-2000 dengan menggunakan tipologi Klassen, Indeks Williamson, Indeks Entropi Theil, Trend dan korelasi Pearson menunjukan bahwa terjadi kecenderungan peningkatan ketimpangan yang salah satunya disebabkan oleh konsentrasi aktivitas ekonomi secara spasial. Hipotesis Kuznets mengenai ketimpangan yang berbentuk kurva U terbalik berlaku di Kabupaten Banyumas. (2). Ikhsan Aprija (2004), menganalisis pola dan struktur pertumbuhan ekonomi dan ketimpangan antar kabupaten di provinsi Sulawesi Barat dengan menggunakan alat analisis tipologi Klassen, Indeks Williamson dan Indeks Entropi Theil, trend dan Korelasi Pearson. Perbedaan yang lain adalah mengenai lokasi, obyek dan periode pengamatan. Penelitian ini berlokasi di wilayah kabupaten majene, menggunakan Produk Domestik Regional Bruto (PDRB) per kapita berdasarkan harga konstan 1993 sebagai dasar perhitungan pertumbuhan, jumlah penduduk Kabupaten Majene, untuk menganalisis ketimpangan antar kabupaten dalam periode tiga tahunm, mulai tahun 2008-2010. (3). Filzah Wadji (2011), meneliti tentang analisis ketimpangan pembangunan provinsi Sulawesi Selatan. Menggunakan analisis Indeks Williamson, hasil analisis menunjukan bahwa terdapat ketimpangan yang terjadi di Provinsi Sulawesi Selatan dengan kecenderungan yang meningkat. Ketimpangan ini terlihat hasil yang ditunjukan di enam tahun terakhir. Hal ini menunjukan betapa tingginya ketimpangan yang terjadi di Provinsi Sulawesi Selatan. (4). Agus Prio Utomo (2013), meneliti tentang ekonomi perencanaan dan pembangunan daerah, analisis pergeseran struktur ekonomi kabupaten Luwu Timur. Menggunakan alat analisis location Quotient (LQ) dengan menggunakan PDRB sebagai indikator pertumbuhan. Hasil penelitian menunjukan bahwa sektor basis di Kabupaten Luwu Timur adalah sektor Pertambangan dan Penggalian, selain itu hasil analisis shift share menunjukan tidak terjadi pergeseran struktur ekonomi di Kab. Luwu Timur pada tahun 2006-2011. Berikut ini gambaran kerangka konsep : 


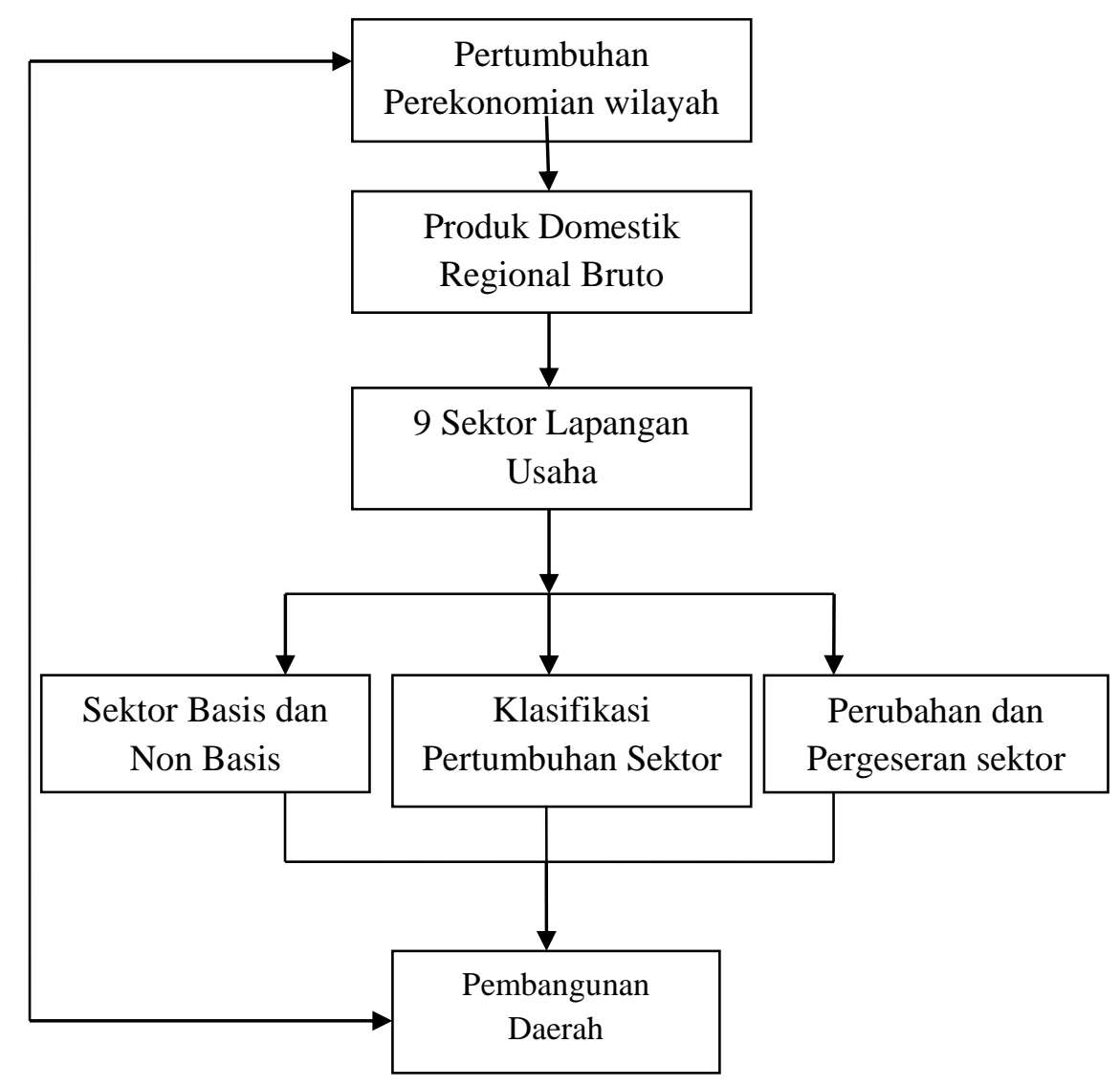

\section{METODE PENELITIAN}

Pendekatan penelitian ini dilakukan menggunakan pendekatan kuantitatif, jenis penelitian ini bersifat studi dokumenter, data yang digunakan bersifat sekunder yang diperoleh dari pihak terkait berupa data-data PDRB (Produk Domestik Regional Bruto) Kabupaten Banggai Laut dan Provinsi Sulawesi Tengah 2009-2013. Adapun analisis data yang digunakan oleh Penulis yaitu :

Analisis yang digunakan untuk mengetahui gambaran tentang klasifikasi pertumbuhan sektor perekonomian dan pergeseran struktur ekonomi serta sektor basis di Kabupaten Banggai Laut yaitu sebagai berikut :

\section{Analisis Sihft Share :}

Analisis Shift Share terbagi atas tiga komponen yaitu : Nasional Share (NS), Proportional Shift (PS), dan Differential Shift (DS) dapat diformulasikan sebagai berikut (Tarigan, 2014).

\section{Nasional Share (NS)}




$$
\mathrm{NS}_{\mathrm{ir}, \mathrm{t}}=\mathrm{E}_{\mathrm{ix}, \mathrm{t}-1} \times\left[\begin{array}{l}
\mathrm{E}_{\mathrm{n}, \mathrm{t}} \\
-\mathrm{E}_{\mathrm{n}, \mathrm{t}-1}
\end{array}\right] .
$$

dimana :

$$
\begin{aligned}
& \mathrm{E}=\text { kesempatan kerja/PDRB Kabupaten Banggai Laut } \\
& \mathrm{t}=\text { periode } \mathrm{t} \\
& \mathrm{t}-1=\text { periode sebelumnya } \\
& \mathrm{i}=\text { sektor/industri tertentu } \\
& \mathrm{r}=\text { daerah tertentu } \\
& \mathrm{n}=\text { nasional }
\end{aligned}
$$

Proportional Shift (PS)

$$
P S_{i r, t}=E_{i r, t-1} \times\left[\left(\frac{E_{i n, t}}{E_{i n, t-1}}\right]-\left[\begin{array}{c}
E_{n, t} \\
-E_{n, t-1}
\end{array}\right]\right)
$$

dimana:

$$
\begin{aligned}
& \mathrm{E}=\text { kesempatan kerja /PDRB } \\
& \mathrm{t}=\text { periode } \mathrm{t} \\
& \mathrm{t}-1=\text { periode sebelumnya (awal) } \\
& \mathrm{i}=\text { sektor/industri tertentu } \\
& \mathrm{r}=\text { daerah tertentu } \\
& \mathrm{n}=\text { nasional } \\
& \text { Differential Shift }(\mathrm{DS})
\end{aligned}
$$

$$
D S_{i r, t}=E_{i r, t-1} \times\left[\left(\frac{E_{i r, t}}{E_{i r, t-1}}\right]-\left[\frac{E_{i n, t}}{E_{i n, t-1}}\right]\right]
$$

dimana:

$$
\begin{aligned}
& \mathrm{E}=\text { kesempatan kerja /PDRB } \\
& \mathrm{t}=\text { periode } \mathrm{t} \\
& \mathrm{t}-1=\text { periode sebelumnya } \\
& \mathrm{i}=\text { sektor/industri tertentu } \\
& \mathrm{r}=\text { daerah tertentu } \\
& \mathrm{n}=\text { nasional }
\end{aligned}
$$

Perubahan (pertumbuhan) nilai tambah bruto sektor tertentu (i) dalam PDRB Kabupaten Banggai Laut merupakan penjumlahan Nasional Share (NS), Proportional Shift (PS), dan Differential Shift (DS) sebagai berikut: Kedua komponen shift, yaitu Proportional Shift (PS) dan Differential Shift (DS) memisahkan unsur-unsur pertumbuhan regional yang bersifat eksternal dan internal. Proportional Shift (PS) merupakan akibat pengaruh unsur- 
unsur eksternal yang bekerja secara nasional (Provinsi), sedangkan Differential Shift (DS) adalah akibat dari pengaruh faktor-faktor yang bekerja di dalam daerah yang bersangkutan

Sektor-sektor di Kabupaten Banggai Laut yang memiliki Differential Shift (DS) positif memiliki keunggulan komparatif terhadap sektor yang sama pada Kabupaten/Kota lain dalam Provinsi Sulawesi Tengah. Selain itu, sektor-sektor yang memiliki nilai DS positif berarti bahwa sektor tersebut terkonsentrasi di Kabupaten Banggai Laut, memiliki daya saing yang tinggi dan mempunyai pertumbuhan yang lebih cepat dibandingkan dengan daerah lainnya. Apabila nilai DS negatif, maka tingkat pertumbuhan sektor tersebut relatif lamban.

\section{Analisis Pergeseran bersih}

Untuk menjawab rumusan masalah dan tujuan penelitian tentang pergeseran struktur ekonomi tidak hanya menggunakan alat analisis shift share tetapi juga digunakan alat analisis pergeseran bersih. Hasil analisis ini akan terlihat pergeseran cepat atau lambat dengan cara menjumlahkan hasil PS dan DS, maka akan diperoleh pergeseran bersih yang dapat digunakan untuk mengidentifikasi pertumbuhan sektor perekonomian. Pergeseran bersih sektor i pada wilayah tertentu dapat dirumuskan sebagai berikut:

$$
P B i j=P S i j+D S i j
$$

dimana:

PBij = pergeseran bersih sektor $\mathrm{i}$ pada wilayah $\mathrm{j}$

PSij = komponen pertumbuhan proporsional sektor $\mathrm{i}$ pada wilayah $\mathrm{j}$

DSij = komponen pertumbuhan pangsa wilayah sektor $\mathrm{i}$ pada wilayah $\mathrm{j}$

Apabila PBij > 0, maka pertumbuhan sektor i pada wilayah j termasuk ke dalam kelompok progresif (maju) $\mathrm{PBij}<0$, maka pertumbuhan sektor $\mathrm{i}$ pada wilayah $\mathrm{j}$ termasuk lamban.

1. Analisis Location Quotient

Untuk mendapatkan nilai LQ menggunakan metode yang mengacu pada formula yang dikemukakan oleh Bendavid-Val dalam Kuncoro (2004) sebagai berikut:

$$
\mathrm{LQ}=\frac{\frac{\text { PDRBbl, } \mathrm{i}}{\Sigma \mathrm{PDRBbl}}}{\frac{\overline{\text { PDRBst }, \mathrm{i}}}{\Sigma \mathrm{PDRBst}}}
$$

Di mana:

PDRBbl,i = PDRB sektor i di Kabupaten Banggai Laut pada tahun tertentu.

$\Sigma$ PDRBbl $=$ Total PDRB di Kabupaten Banggai Laut pada tahun tertentu. 
PDRBst, $i=$ PDRB sektor i di Provinsi Sulawesi Tengah pada tahun tertentu . $\Sigma$ PDRBst $=$ Total PDRB di Provinsi Sulawesi Tengah pada tahun tertentu.

Berdasarkan formulasi yang ditunjukkan dalam persamaan di atas, maka ada tiga kemungkinan nilai LQ yang dapat diperoleh Bendavid-Val dalam (Kuncoro,2004) yaitu : 1) Nilai LQ $=1$. Ini berarti bahwa tingkat spesialisasi/basis sektor i di daerah Kabupaten Banggai Laut adalah sama dengan sektor yang sama dalam perekonomian Provinsi Sulawesi Tengah, 2) Nilai LQ > 1. Ini berarti bahwa tingkat spesialisasi/basis sektor i di daerah Kabupaten Banggai Laut lebih besar dibandingkan dengan sektor yang sama dalam perekonomian Provinsi Sulawesi Tengah, 3) Nilai LQ $<1$. Ini berarti bahwa tingkat spesialisasi/basis sektor i di daerah Kabupaten Banggai Laut lebih kecil dibandingkan dengan sektor yang sama dalam perekonomian Provinsi Sulawesi Tengah.

\section{HASIL DAN PEMBAHASAN}

Adapun hasil Analisis Shift Share PDRB Kabupaten Banggai Laut menurut lapangan usaha tahun 2009 - 2013 dapat dilihat pada tabel 1. dibawah :

Tabel 1. Komponen Perubahan PDRB Kabupaten Banggai Laut menurut lapangan usaha 2009 - 2013 (juta rupiah).

\begin{tabular}{|c|c|c|c|c|c|c|c|}
\hline \multirow{2}{*}{ No } & \multirow{2}{*}{ Sektor Ekonomi } & \multicolumn{2}{|c|}{$\begin{array}{c}\text { PDRB } \\
\text { Kab.Banggai Laut }\end{array}$} & \multirow[t]{2}{*}{$\begin{array}{c}\text { Peruba } \\
\text { han }\end{array}$} & \multicolumn{3}{|c|}{ Komponen Perubahan } \\
\hline & & 2009 & 2013 & & $\begin{array}{l}\text { Nasional } \\
\text { Share ( NS) }\end{array}$ & $\begin{array}{l}\text { Proportional } \\
\text { Shift (PS) }\end{array}$ & $\begin{array}{l}\text { Differential } \\
\text { shift (DS) }\end{array}$ \\
\hline 1 & Pertanian & 140.397 & 186.329 & 45.932 & $58.660,2175$ & $-21.281,61906$ & $8.553,401551$ \\
\hline 2 & Penggalian & 1.408 & 1.887 & 479 & 588,285977 & $2.442,684218$ & $-2.551,970195$ \\
\hline 3 & Industri Pengolahan & 10.949 & 14.691 & 3.742 & $4.574,675541$ & $-2.063,734221$ & $1.231,05868$ \\
\hline 4 & $\begin{array}{l}\text { Listrik, Gas dan Air } \\
\text { bersih }\end{array}$ & 1.587 & 2.453 & 866 & 663,0751743 & $-117,260484$ & 320,1853096 \\
\hline 5 & Bangunan & 2.634 & 3.858 & 1.224 & $1.100,529306$ & 723,937695 & $-600,4670013$ \\
\hline 6 & $\begin{array}{l}\text { Perdagangan ,Hotel } \\
\text { dan Restoran }\end{array}$ & 47.046 & 70.454 & 23.408 & $19.656,60659$ & $-902,2015443$ & $4.653,594959$ \\
\hline 7 & $\begin{array}{l}\text { Angkutan dan } \\
\text { Komunikasi }\end{array}$ & 16.714 & 24.234 & 7.520 & $6.983,389076$ & $-586,4358637$ & $1.123,046788$ \\
\hline 8 & $\begin{array}{l}\text { Keuangan, } \\
\text { Persewaan dan Jasa } \\
\text { Perusahaan }\end{array}$ & 13.512 & 19.189 & 5.677 & $5.645,539858$ & 829,465103 & $-798,0049614$ \\
\hline 9 & Jasa-jasa & 20.790 & 28.189 & 7.399 & $8.686,410129$ & $-660,2872629$ & $-627,1228656$ \\
\hline & Jumlah & 255.037 & 351.284 & 96.247 & $106.558,7292$ & $-21.615,45142$ & $11.303,72226$ \\
\hline
\end{tabular}

Sumber : BPS Kab. Balut dan Prov. Sulteng, serta hasil analisis. 
Hasil analisis shift share pada Tabel 1. menunjukkan bahwa perubahan yang terjadi pada PDRB Kabupaten Banggai Laut dari tahun 2009 hingga 2013 sebesar 96.247 juta rupiah dari jumlah tersebut sebagian besar (76,4 persen atau 106.558,73 juta rupiah) disebabkan oleh perubahan karena efek pertumbuhan nasional dalam hal ini Sulawesi Tengah, hal ini menunjukkan bahwa perekonomian Kabupaten Banggai Laut masih sangat bergantung pada perekonomian Sulawesi Tengah dan nasional bahkan global.

Sementara itu pengaruh dari efek bauran industri/sektoral (industrial mix growth) terhadap pertumbuhan ekonomi Kabupaten Banggai Laut masih bernilai negatif, yakni sebesar negatif 15,5 persen atau negatif $21.615,45$ juta rupiah. Hal ini berarti pengaruh efek bauran industri/sektoral belum mampu mendorong pertumbuhan ekonomi Kabupaten Banggai Laut, Sehingga dapat dikatakan bahwa sektor yang di kembangkan pada Kabupaten Banggai Laut tidak sesuai dengan sektor yang di kembangkan di tingkat propinsi dalam hal ini Sulawesi Tengah.

Sedangkan pengaruh daya saing Kabupaten Banggai Laut terhadap perekonomian Kabupaten Banggai Laut itu sendiri, cukup baik karena telah mampu mendorong pertumbuhan ekonomi di Kabupaten Banggai Laut, yakni sebesar 8,102 persen atau 11.303,72 juta rupiah. Akan tetapi hal ini masih lebih rendah dibanding dengan pengaruh komponen pertumbuhan ekonomi Sulawesi Tengah (NS) yakni sebesar 106.558,73 juta rupiah

Tabel 2. Komponen perubahan pergeseran bersih PDRB Kabupaten Banggai Laut menurut lapangan usaha, 2009 dan 2013 (juta rupiah)

\begin{tabular}{|c|c|c|c|c|c|c|c|c|}
\hline \multirow{2}{*}{$\begin{array}{l}\mathrm{N} \\
\mathrm{O}\end{array}$} & \multirow{2}{*}{$\begin{array}{l}\text { Sektor } \\
\text { Ekonomi }\end{array}$} & \multicolumn{2}{|c|}{$\begin{array}{c}\text { PDRB } \\
\text { Kab.Banggai } \\
\text { Laut } \\
\end{array}$} & \multirow[t]{2}{*}{$\begin{array}{l}\text { Peruba } \\
\text { han }\end{array}$} & \multicolumn{3}{|c|}{ Komponen Perubahan } & \multirow[t]{2}{*}{$\begin{array}{l}\text { Pergeseran } \\
\text { Bersih }\end{array}$} \\
\hline & & 2009 & 2013 & & $\begin{array}{c}\text { Nasional } \\
\text { Share ( NS) }\end{array}$ & $\begin{array}{l}\text { Proportional } \\
\text { Shift (PS) }\end{array}$ & $\begin{array}{l}\text { Differential } \\
\text { shift (DS) }\end{array}$ & \\
\hline 1 & Pertanian & 140.397 & $\begin{array}{r}186.32 \\
9 \\
\end{array}$ & 45.932 & $58.660,2175$ & $-21.281,61906$ & $8.553,401551$ & $-12.728,2175$ \\
\hline 2 & Penggalian & 1.408 & 1.887 & 479 & 588,285977 & $2.442,684218$ & $-2.551,970195$ & $-109,285977$ \\
\hline 3 & $\begin{array}{l}\text { Industri } \\
\text { Pengolahan }\end{array}$ & 10.949 & 14.691 & 3.742 & $4.574,675541$ & $-2.063,734221$ & $1.231,05868$ & $-832,675541$ \\
\hline 4 & $\begin{array}{l}\text { Listrik, Gas dan } \\
\text { Air bersih }\end{array}$ & 1.587 & 2.453 & 866 & 663,0751743 & $-117,260484$ & 320,1853096 & 202,9248257 \\
\hline 5 & Bangunan & 2.634 & 3.858 & 1.224 & $1.100,529306$ & 723,937695 & $-600,4670013$ & 123,4706937 \\
\hline 6 & $\begin{array}{l}\text { Perdagangan } \\
\text {,Hotel dan } \\
\text { Restoran }\end{array}$ & 47.046 & 70.454 & 23.408 & $19.656,60659$ & $-902,2015443$ & $4.653,594959$ & $3.751,393415$ \\
\hline 7 & $\begin{array}{l}\text { Angkutan dan } \\
\text { Komunikasi }\end{array}$ & 16.714 & 24.234 & 7.520 & $6.983,389076$ & $-586,4358637$ & $1.123,046788$ & 536,6109241 \\
\hline
\end{tabular}




\begin{tabular}{|c|l|r|r|r|r|r|r|r|}
\hline 8 & $\begin{array}{l}\text { Keuangan, } \\
\text { Persewaan dan } \\
\text { Jasa Perusahaan }\end{array}$ & 13.512 & 19.189 & 5.677 & $5.645,539858$ & 829,465103 & $-798,0049614$ & 31,46014156 \\
\hline 9 & Jasa-jasa & 20.790 & 28.189 & 7.399 & $8.686,410129$ & $-660,2872629$ & $-627,1228656$ & $1.287,410129$ \\
\hline & Jumlah & 255.037 & $\begin{array}{c}351.28 \\
4\end{array}$ & 96.247 & $106.558,7292$ & $-21.615,45142$ & $11.303,72226$ & - \\
& & & & & & $10.311,72915$ \\
\hline
\end{tabular}

Pergeseran bersih (PB) diperoleh dari hasil penjumlahan antara proportional shift dan differential shift di setiap sektor perekonomian. Apabila $\mathrm{PB}>0$, Maka pertumbuhan sektor di Banggai Laut termasuk dalam kelompok yang progresif (maju). Sedangkan $\mathrm{PB}<0$ artinya sektor perekonomian di Banggai Laut termasuk kelompok yang lamban.

Berdasarkan Tabel 2, secara agregat pergeseran bersih di Kabupaten Banggai Laut menghasilkan nilai negatif yakni sebesar minus 10.311,73 juta rupiah. Hal ini juga menunjukkan bahwa secara umum Kabupaten Banggai Laut termasuk ke dalam kelompok daerah yang lamban. Di tingkat sektoral, lima sektor yang memiliki nilai PB $>0$ atau sektor yang pertumbuhannya progresif (maju) yaitu listrik gas dan air bersih, bangunan, perdagangan, hotel dan restoran, pengangkutan dan komunikasi, dan keuangan dan persewaan. Sedangkan sektor yang tergolong lamban atau $\mathrm{PB}<0$ yaitu pertanian, penggalian, industri pengolahan dan jasa-jasa.

Tabel 3. Komponen perubahan dan kenaikan aktual PDRB Kabupaten Banggai Laut menurut lapangan usaha, 2009 dan 2013 (persen).

\begin{tabular}{|c|c|c|c|c|c|c|c|}
\hline \multirow[b]{2}{*}{ No } & \multirow[b]{2}{*}{ Sektor Ekonomi } & \multicolumn{3}{|c|}{ Komponen Perubahan } & \multirow{2}{*}{$\begin{array}{c}\text { Efek } \\
\text { Bersih } \\
(\%)\end{array}$} & \multirow{2}{*}{$\begin{array}{c}\text { Kenaikan } \\
\text { Aktual } \\
(\%)\end{array}$} & \multirow[b]{2}{*}{ Rangking } \\
\hline & & NS & PS & DS & & & \\
\hline 1 & Pertanian & 41,78 & $-15,16$ & 6,0923 & $-9,066$ & 32,72 & IX \\
\hline 2 & Penggalian & 41,78 & 173,49 & $-181,2$ & $-7,762$ & 34,02 & VIII \\
\hline 3 & Industri Pengolahan & 41,78 & $-18,85$ & 11,244 & $-7,605$ & 34,18 & VII \\
\hline 4 & $\begin{array}{l}\text { Listrik, Gas dan Air } \\
\text { bersih }\end{array}$ & 41,78 & $-7,389$ & 20,176 & 12,79 & 54,57 & I \\
\hline 5 & Bangunan & 41,78 & 27,484 & $-22,8$ & 4,688 & 46,47 & III \\
\hline 6 & $\begin{array}{l}\text { Perdagangan ,Hotel dan } \\
\text { Restoran }\end{array}$ & 41,78 & $-1,918$ & 9,8916 & 7,974 & 49,76 & II \\
\hline 7 & $\begin{array}{l}\text { Angkutan dan } \\
\text { Komunikasi }\end{array}$ & 41,78 & $-3,509$ & 6,7192 & 3,211 & 44,99 & IV \\
\hline 8 & $\begin{array}{l}\text { Keuangan dan } \\
\text { Persewaan }\end{array}$ & 41,78 & 6,1387 & $-5,906$ & 0,233 & 42,01 & V \\
\hline
\end{tabular}




\begin{tabular}{l|l|l|l|l|l|l|l|}
9 & Jasa-jasa & 41,78 & $-3,176$ & $-3,016$ & $-6,192$ & 35,59 & VI \\
\hline
\end{tabular}

Berdasarkan hasil analisis pada Tabel 3 terlihat jelas bahwa Kabupaten Banggai Laut telah mengalami pergeseran struktur dari sektor primer ke sektor sekunder dan tersier, hal ini ditandai dengan rendahnya kenaikan aktual pada sektor pertanian sehingga menempatkan sektor tersebut pada posisi ke sembilan atau rangking sembilan dari seluruh sektor perekonomian, berarti sektor pertanian mulai mengalami penurunan dalam memberikan kontribusi terhadap PDRB Kabupaten Banggai Laut, meskipun demikian sektor pertanian harus tetap menjadi perhatian utama mengingat sektor primer atau sektor pertanian sangat berperan guna mendorong peningkatan sektor lainnya atau sektor sekunder dan tersier.

Adapun sektor yang mengalami kenaikan aktual tertinggi dan menempatkan sektor tersebut pada urutan pertama atau rangking satu adalah sektor listrik, gas dan air bersih sebesar 54,57 persen, hal ini berarti sektor listrik, gas dan air bersih merupakan sektor dengan laju pertumbuhan yang cepat atau merupakan sektor yang sangat berpotensi untuk dikembangkan, sejalan dengan hal ini pada tahun 2015 ini, pemerintah daerah Kabupaten Banggai Laut telah mengupayakan bagi pengadaan pembangkit listrik tenaga uap sebesar 2 unit, yang berada di kecamatan labobo dan kecamatan bangkurung.

Kemudian sektor perdagangan, hotel dan restoran berada pada urutan kedua dengan kenaikan aktual sebesar 49,76 persen, hal ini berarti sektor tersebut pertumbuhanya sangat cepat, hal ini membuktikan bahwa lokasi Kabupaten Banggai Laut yang merupakan jalur perdagangan dan transportasi.

Dengan demikian perubahan struktur Kabupaten Banggai Laut ditandai dengan beralihnya peranan sektor primer secara perlahan yang kemudian menuju sektor sekunder dan tersier, hal ini ditunjukkan pada tabel 3. yang menempatkan sektor pertanian pada urutan ke sembilan dan sekor listrik, gas dan air bersih pada urutan pertama, kemudian disusul oleh sektor perdagangan, hotel dan restoran, dan pada urutan ketiga ditempati oleh sektor Bangunan, selanjutnya sektor Angkutan dan komunikasi, sektor keuangan dan Persewaan, sektor jasa-jasa, sektor industri pengolahan dan sektor Penggalian.

\section{Analisis Kuadran}

Dengan melihat besaran PS dan DS, maka suatu daerah/sektor dapat dikategorikan menjadi empat kelompok/kuadran, dari Gambar 1. diatas, pada periode 2009-2013 secara agregat posisi perekonomian (PDRB) Kabupaten Banggai Laut hanya menempati tiga kuadran, dan terlihat jelas pada Gambar 1, bahwa sembilan sektor ekonomi di Kabupaten 
Banggai Laut tidak satupun yang menempati kuadran I (PS positif dan DS positif) yaitu berdaya saing tinggi dan berdaya dukung tinggi. Hal ini membuktikan bahwa pertumbuhan sektor ekonomi di Kabupaten Banggai Laut belum cukup baik.

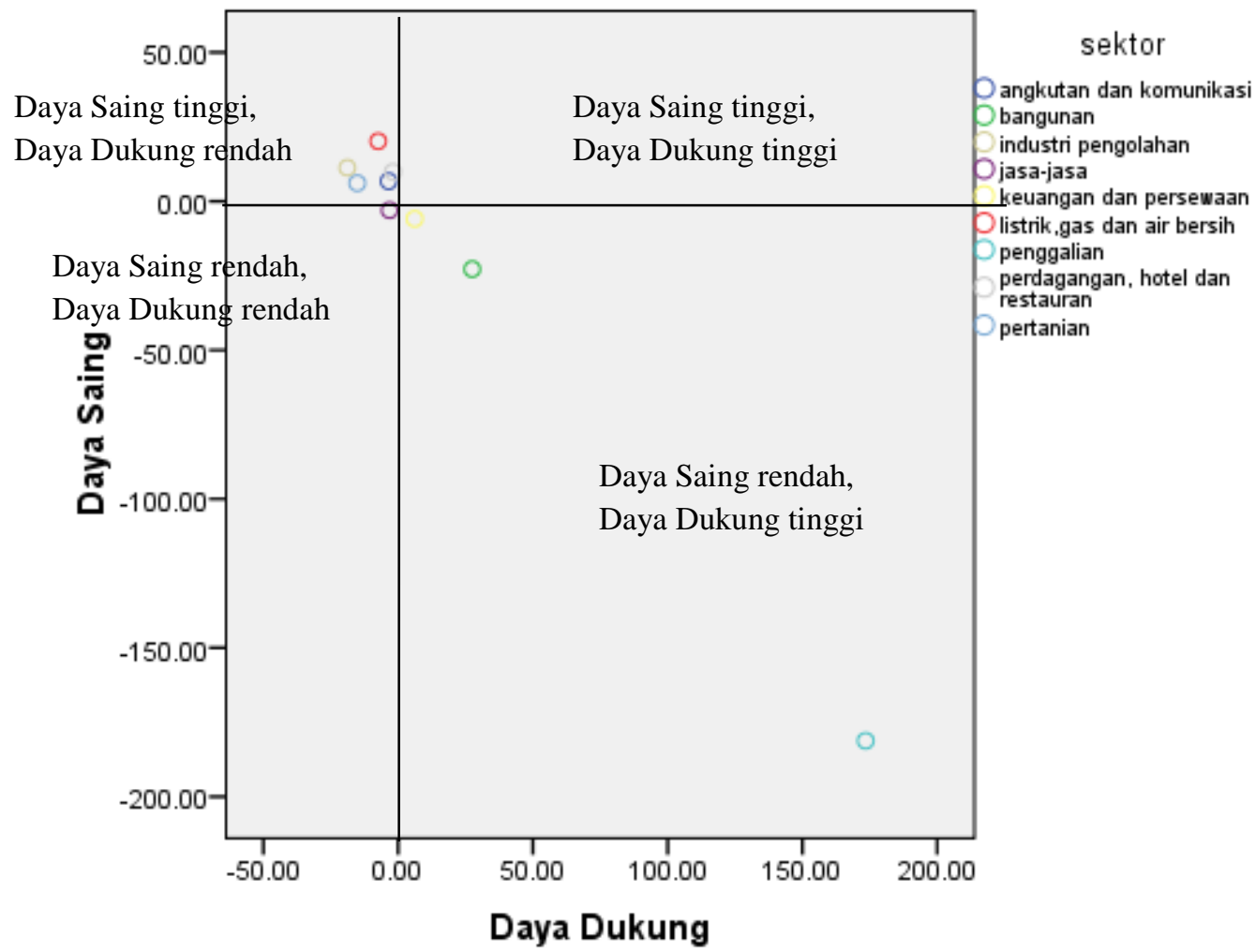

Gambar 1. Proportional shift (Daya Dukung) dan Diference shift (Daya saing) sektor ekonomi di Kab. Banggai Laut 2009-2013.

Terdapat lima sektor yang menempati kuadran II (PS negatif dan DS positif), yaitu listrik, gas, dan air bersih, angkutan dan komunikasi, perdagangan, hotel dan restauran, pertanian, dan industri pengolahan. Sektor ini memiliki kecenderungan sektor yang lemah namun berpotensi untuk dikembangkan, kelompok sektor ini memiliki tingkat daya saing tinggi namun laju pertumbuhannya lambat karena daya dukung yang rendah.

Pada kuadran III (PS positif dan DS negatif) ditempati oleh sektor keuangan dan persewaan, bangunan, dan penggalian. Ini menunjukan bahwa sektor tersebut berada sebagai sektor ekonomi yang memiliki laju pertumbuhan yang cepat secara nasional (provinsi), tetapi sektor tersebut tidak dapat bersaing dengan sektor ekonomi dari wilayah lain karena berdaya saing rendah.

Kuadran IV (PS negatif dan DS negatif) ditempati oleh sektor jasa-jasa. Hal ini menunjukan sektor ini memiliki pertumbuhan yang lambat dan berdaya saing rendah, 
sehingga sektor tersebut saat ini tidak bisa di jadikan sektor andalan di Kabupaten Banggai Laut.

\section{Sektor Basis dan non Basis di Kab. Banggai Laut}

Tabel 4. Nilai Location Quotient Banggai Laut per Sektor Ekonomi tahun 2009-2013

\begin{tabular}{|c|l|c|c|c|c|c|}
\hline \multirow{2}{*}{ No } & \multirow{2}{*}{ Lapangan usaha } & \multicolumn{5}{|c|}{ Tahun } \\
\cline { 4 - 8 } & & 2009 & 2010 & 2011 & 2012 & 2013 \\
\hline 1 & Pertanian & 1,34 & 1,36 & 1,38 & 1,41 & 1,44 \\
\hline 2 & Penggalian & 0,15 & 0,12 & 0,09 & 0,08 & 0,06 \\
\hline 3 & Industri pengolahan & 0,66 & 0,67 & 0,70 & 0,72 & 0,74 \\
\hline 4 & Listrik gas dan air bersih & 0,84 & 0,90 & 0,94 & 0,97 & 1,00 \\
\hline 5 & Bangunan & 0,15 & 0,15 & 0,14 & 0,13 & 0,13 \\
\hline 6 & Perdagangan, hotel dan restoran & 1,43 & 1.45 & 1,50 & 1,52 & 1,58 \\
\hline 7 & Pengangkutan dan komunikasi & 0,86 & 0,86 & 0,88 & 0,91 & 0,93 \\
\hline 8 & Keuangan dan persewaan & 1,12 & 1,10 & 1,11 & 1,13 & 1,10 \\
\hline 9 & Jasa-jasa & 0,50 & 0,49 & 0,50 & 0,50 & 0,50 \\
\hline
\end{tabular}

Sumber : BPS (diolah).

Alat analisis Location Quotient (LQ) digunakan untuk mengidentifikasi keunggulan komparatif kegiatan ekonomi di Banggai Laut dengan membandingkannya pada tingkat propinsi dalam hal ini Sulawesi Tengah. Teori location quetion seperti dikemukakan Bendavid digunakan untuk menganalisis keragaman basis ekonomi. Dari analisis tersebut dapat diidentifikasi sektor-sektor apa saja yang dapat dikembangkan untuk tujuan ekspor dan tujuan menyuplai kebutuhan lokal, sehingga sektor yang dikatakan potensial dapat dijadikan sektor prioritas utama dalam perencanaan pembangunan ekonomi. Berdasarkan analisis LQ pada Tabel 4, di Banggai Laut terdapat empat sektor-sektor ekonomi yang memiliki keunggulan komparatif (nilai LQ>1), yaitu : sektor pertanian, listrik, gas dan air bersih, perdagangan, hotel dan restoran, dan keuangan dan persewaan. Hal ini mengindikasikan bahwa keempat sektor tersebut telah mampu menyuplai kebutuhan lokal dan melakukan ekspor keluar daerah. 
Tabel 5. Matriks kesimpulan dan Rekomendasi

\begin{tabular}{|c|c|c|}
\hline No & Kesimpulan & Rekomendasi (Saran) \\
\hline \multicolumn{3}{|c|}{ Sektor Pertanian } \\
\hline 1. & $\begin{array}{l}\text { Sektor Pertanian masih } \\
\text { menjadi sektor terpenting } \\
\text { dalam pertumbuhan } \\
\text { ekonomi di Kabupaten } \\
\text { Banggai Laut, selain } \\
\text { berdaya saing tinggi sektor } \\
\text { ini pula merupakan sektor } \\
\text { basis ekonomi, namun } \\
\text { sektor ini masih berdaya } \\
\text { dukung yang lemah dan } \\
\text { secara nasional } \\
\text { pertumbuhannya cenderung } \\
\text { lambat. }\end{array}$ & $\begin{array}{l}\text { a. Memfasilitasi industri manufaktur } \\
\text { guna meningkatkan nilai tambah } \\
\text { hasil-hasil pertanian khususnya } \\
\text { komoditi kakao(coklat), kelapa dan } \\
\text { cengkeh serta hasil-hasil perikanan. } \\
\text { b. Memperlancar dan mengefisienkan } \\
\text { jalur distribusi dalam maupun luar } \\
\text { daerah. } \\
\text { c. Peningkatan kualitas produk } \\
\text { pertanian serta perbaikan akses } \\
\text { petani dalam hal permodalan dan } \\
\text { pemasaran hasil untuk } \\
\text { meningkatkan posisi tawar petani. }\end{array}$ \\
\hline \multicolumn{3}{|c|}{ Sektor Penggalian } \\
\hline 2. & $\begin{array}{l}\text { Sektor Penggalian } \\
\text { merupakan sektor terkecil } \\
\text { terhadap struktur PDRB di } \\
\text { Banggai laut, dan sektor ini } \\
\text { juga mempunyai daya saing } \\
\text { yang lemah,dan bukan } \\
\text { merupakan sektor basis } \\
\text { ekonomi, namun sektor ini } \\
\text { mempunyai daya dukung } \\
\text { yang kuat. }\end{array}$ & $\begin{array}{l}\text { Melihat permintaan pada sektor ini secara } \\
\text { agregat meningkat maka perlunya regulasi } \\
\text { yang tegas terhadap pelaku-pelaku } \\
\text { penggalian ilegal karena sumber daya alam } \\
\text { pada sektor ini di Kabupaten Banggai Laut } \\
\text { relatif kecil. }\end{array}$ \\
\hline \multicolumn{3}{|c|}{ Sektor Industri Pengolahan } \\
\hline 3. & $\begin{array}{l}\text { Sektor Industri Pengolahan } \\
\text { merupakan sektor potensial } \\
\text { untuk menjadi leading } \\
\text { sektor di Banggai Laut } \\
\text { karena sektor ini memiliki } \\
\text { daya saing yang kuat dan } \\
\text { walaupun sektor ini belum } \\
\text { merupakan sektor basis, } \\
\text { namun sepanjang tahun } \\
\text { penelitian nilai LQ sektor } \\
\text { tersebut terus meningkat. } \\
\text { Akan tetapi secara nasional / } \\
\text { provinsi pertumbuhan sektor } \\
\text { ini cenderung lambat hal ini } \\
\text { disebabkan struktur } \\
\text { ekonomi daerah yang } \\
\text { kurang baik. }\end{array}$ & $\begin{array}{l}\text { Mendorong investasi dengan cara: } \\
\text { a. Mendatangkan investor-investor } \\
\text { swasta khususnya pada perusahaan- } \\
\text { perusahaan yang bergerak di bidang } \\
\text { pengelolaan hasil-hasil perikanan. } \\
\text { b. Mendirikan BUMD } \\
\text { Menciptakan entrepreneur-entreprneur } \\
\text { baru melalui pelatihan-pelatihan yang } \\
\text { diselenggarakan oleh Pemerintah Daerah. } \\
\text { Menciptakan Good Governance yang baik. }\end{array}$ \\
\hline \multicolumn{3}{|c|}{ Sektor Listrik dan Air Bersih } \\
\hline
\end{tabular}




\begin{tabular}{|c|l|l|}
\hline 4. & Sektor listrik dan air bersih & Peningkatan pelayanan melalui \\
& pada tahun 2013 sudah & pembangunan PLTD-PLTD di daerah yang \\
& merupakan sektor basis, & berkembang, karena sektor ini merupakan \\
& sektor ini juga berdaya saing & sektor basis yang berarti mempunyai \\
& kuat, namun masih memiliki & multiplier effect atau mendorong sektor- \\
& struktur ekonomi yang & sektor yang lain seperti Industri \\
& kurang baik karena & Pengolahan, Perdagangan, \\
kurangnya produktifitas atau & angkutan,komunikasi, dll bisa berkembang. \\
sisi penawaran secara & \\
agregat. & \\
\hline
\end{tabular}

\begin{tabular}{|c|c|c|}
\hline No & Kesimpulan & Rekomendasi (Saran) \\
\hline \multicolumn{3}{|c|}{ Sektor Bangunan } \\
\hline 5. & $\begin{array}{l}\text { Sektor bangunan di Banggai } \\
\text { laut bukan merupakan sektor } \\
\text { basis dan sektor ini juga } \\
\text { mempunyai daya saing yang } \\
\text { rendah, akan tetapi pada } \\
\text { sektor ini memiliki struktur } \\
\text { ekonomi daerah yang baik, } \\
\text { hal ini disebabkan karena } \\
\text { permintaan secara agregat } \\
\text { masih cukup baik. }\end{array}$ & $\begin{array}{l}\text { Meningkatkan daya saing melalui : } \\
\text { a. Penyediaan prasarana pendukung } \\
\text { pembangunan }\end{array}$ \\
\hline \multicolumn{3}{|c|}{ Sektor Perdagangan, hotel dan restoran } \\
\hline 6. & $\begin{array}{l}\text { Sektor perdagangan, hotel } \\
\text { dan restoran merupakan } \\
\text { sektor unggulan atau sektor } \\
\text { basis ekonomi di Banggai } \\
\text { Laut, sektor ini juga } \\
\text { memiliki daya saing yang } \\
\text { kuat, namun daya dukung } \\
\text { pada sektor ini cenderung } \\
\text { lemah hal ini disebabkan } \\
\text { karena sisi permintaan secara } \\
\text { agregat masih relatif rendah }\end{array}$ & $\begin{array}{l}\text { Peningkatan daya dukung melalui : } \\
\text { a. Penyediaan sarana dan prasarana } \\
\text { pendukung. } \\
\text { b. Mendirikan fasilitas-fasilitas } \\
\text { publik sebagai penarik urbanisasi } \\
\text { sehingga mendorong permintaan } \\
\text { pada sektor ini meningkat. } \\
\text { c. Memperlancar jalur distribusi } \\
\text { barang dan jasa yang efisien. }\end{array}$ \\
\hline \multicolumn{3}{|c|}{ Sektor Angkutan dan Komunikasi } \\
\hline 7. & $\begin{array}{l}\text { Sektor Angkutan dan } \\
\text { Komunikasi di banggai Laut } \\
\text { belum merupakan sektor } \\
\text { basis akan tetapi selama } \\
\text { tahun penelitian (2009-2013) } \\
\text { nilai LQ pada sektor ini terus } \\
\text { mengalami peningkatan dan } \\
\text { pada tahun } 2013 \text { nilai LQ } \\
\text { telah mencapai 0,93 yang } \\
\text { menunjukan sektor ini } \\
\text { potensial sebagai sektor } \\
\text { unggulan di Kab. Banggai }\end{array}$ & $\begin{array}{l}\text { Peningkatan pada sisi penawaran melalui } \\
\text { a. Pembangunan jaringan } \\
\text { telekomunikasi dan sarana, } \\
\text { prasarana seperti jalan } \\
\text { penghubung dan pelabuhan- } \\
\text { pelabuhan di wilayah-wilayah } \\
\text { berkembang seperti Kecamatan } \\
\text { Bokan Kepulauan dan } \\
\text { Bangkurung. }\end{array}$ \\
\hline
\end{tabular}




\begin{tabular}{|l|l|l|}
\hline Laut sektor ini juga memiliki \\
daya saing yang kuat namun \\
masih berdaya dukung \\
lemah, hal ini disebabkan \\
pada sisi penawaran yang \\
masih rendah
\end{tabular}

\begin{tabular}{|c|c|c|}
\hline No & Kesimpulan & Rekomendasi (Saran) \\
\hline \multicolumn{3}{|c|}{ Sektor Keuangan dan Persewaan } \\
\hline 8. & $\begin{array}{l}\text { Sektor Keuangan dan } \\
\text { Persewaan di Banggai Laut } \\
\text { merupakan sektor unggulan } \\
\text { atau basis ekonomi di } \\
\text { Kabupaten Banggai laut, } \\
\text { sektor ini juga secara } \\
\text { Provinsi mempunyai } \\
\text { pertumbuhan yang cepat } \\
\text { akan tetapi pada sektor ini } \\
\text { masih memiliki daya saing } \\
\text { yang lemah. }\end{array}$ & $\begin{array}{l}\text { Peningkatan daya saing melalui : } \\
\text { a. Perbaikan regulasi Pemerintah } \\
\text { daerah dalam pengembangan sektor } \\
\text { ini } \\
\text { b. Perbaikan birokrasi yang bersifat } \\
\text { efisien }\end{array}$ \\
\hline \multicolumn{3}{|c|}{ Sektor Jasa-jasa } \\
\hline 9. & $\begin{array}{l}\text { Sektor jasa-jasa di Banggai } \\
\text { Laut bukan merupakan } \\
\text { sektor basis, namun sektor } \\
\text { ini menempati urutan ketiga } \\
\text { terhadap struktur PDRB } \\
\text { Kab. Banggai laut. Akan } \\
\text { tetapi sektor ini masih } \\
\text { memiliki daya saing dan } \\
\text { daya dukung yang rendah. }\end{array}$ & $\begin{array}{l}\text { Peningkatan daya saing dan daya dukung } \\
\text { seperti : } \\
\text { a. Penyediaan Sarana dan prasarana } \\
\text { pendukung }\end{array}$ \\
\hline
\end{tabular}

\section{KESIMPULAN DAN SARAN}

Sektor Pertanian masih menjadi sektor terpenting dalam pertumbuhan ekonomi di Kabupaten Banggai Laut, Sektor Penggalian merupakan sektor terkecil terhadap struktur PDRB di Banggai laut, Sektor Industri Pengolahan merupakan sektor potensial untuk menjadi leading sector, Sektor listrik dan air bersih pada tahun 2013 sudah merupakan sektor basis, Sektor bangunan di Banggai laut bukan merupakan sektor basis, Sektor perdagangan, hotel dan restoran merupakan sektor unggulan, Sektor Angkutan dan Komunikasi di banggai Laut belum merupakan sektor basis, Sektor Keuangan dan Persewaan di Banggai Laut merupakan sektor unggulan, Sektor jasa-jasa di Banggai Laut bukan merupakan sektor basis. 
Berdasarkan hal tersebut maka disarankan perlunya Peningkatan daya saing melalui berbagai strategi khususnya sektor yang masih potensial dan unggulan.

\section{DAFTAR PUSTAKA}

Adisasmita, R, 2013, Teori-teori Pembangunan Ekonomi, Pertumbuhan Ekonomi dan Pertumbuhan Wilayah, Edisi Pertama, Yogyakarta.: Penerbit Graha Ilmu,

Agus Prio Utomo, 2013. Ekonomi Perencanaan dan Pembangunan daerah Analisis Pergeseran Struktur Ekonomi Kabupaten Luwu Timur.

Arsyad, Lincoln, 2004, Ekonomi Pembangunan, Edisi keempat, Yogyakarta: STIE YKPN,

Kuncoro, Mudrajad dan Aswandi, HS, 2004, Otonomi Pembangunan Daerah, Jakarta : Erlangga.

Sjafrizal, 2014, Ekonomi Wilayah dan Perkotaan, cetakan kedua Jakarta.: Rajagrafindo Persada,

Tarigan, Robinson, 2014, Ekonomi regional, Teori dan Aplikasi, Cetakan ketujuh, Jakarta : PT. Bumi Aksara,

Todaro, Michael, 2004, Pembangunan Ekonomi Di dunia Ketiga, Edisi Kedelapan, Jakarta. :Elangga

UU. No. 32 Tahun 2004. Tentang Pemerintah Daerah, Sinar Grafika, Jakarta

UU. No. 33 Tahun 2004. Tentang Perimbangan Keuangan Pemerintah Pusat Dan Pemerintah Daerah. Sinar Grafika, Jakarta

Wadji, Filzah. 2011. Analisis Ketimpangan Pembangunan Provinsi Sulawesi Selatan. Tesis Magister Sains. Program Studi Ilmu Perencanaan Pembangunan Wilayah dan Pedesaan, Program Pasca Sarjana, IPB, Bogor 